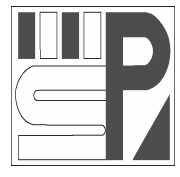

Science Press
Journal of Arid Land

2012, 4(3): 292-299

doi: 10.3724/SP.J.1227.2012.00292

jal.xjegi.com; www.chinasciencejournal.com

\title{
The effect of water spreading system on the functionality of rangeland ecosystems
}

\author{
Mohammad Rahim FOROUZEH, Mohsen SHARAFATMANDRAD* \\ PhD Student of Rangeland Science, Gorgan University of Agricultural Sciences and Natural Resources, Gorgan 49138-15739, Iran
}

\begin{abstract}
In recent decades, the control of floods is an efficient management practice for the rehabilitation of rangelands in most arid and semiarid areas. To evaluate the benefits, we used the Landscape Function Analysis (LFA) method to assess the function of patches and qualitative capability of a rangeland ecosystem in Gareh Bygone region, Fars province, southwestern Iran. Landscape functionality depends on soil, water and nutrient (collectively called "resources") conservation and use within a given ecosystem. Many landscapes are naturally heterogeneous in terms of resource control and possess patches, where resources tend to accumulate, and inter-patches. Assessing rangeland health and function of landscape patches in response to environment and management can give rise to correct management decisions for qualitative improvement of the ecosystem. Therefore, our study area was divided into two parts, i.e. water spreading and control parts, and sampling was done using LFA method in each part separately. Structural parameters, including the number, length and width of patches, and the mean length of inter-patches, were determined by the method to characterize the functional status of the monitoring sites. For each patch/inter-patch type identified in the transect organization log, we recorded its soil surface properties classified according to the Soil Surface Assessment Method. The density, canopy cover and composition of plants were then assessed. The results showed that the number of ecological patches and their dimensions were significantly increased in the water spreading site. Soil stability and the values of nutrient cycling indices were increased but the infiltration values were decreased in the water spreading site. It could be related to the effect of suspended materials transported by floods to the soils in the study area. The improvement of ecological patches and rangeland ecosystem was achieved where water spreading systems were practiced. Therefore it can be concluded that water spreading as a management plan plays an important role in arid land ecosystem functionality.
\end{abstract}

Keywords: ecological patch; landscape function analysis; water spreading; arid lands

There is a close relationship between hydrological processes and vegetation, especially in water-limited environments. In particular, vegetation pattern is a composite of fertile patches with high biomass and bare open soil in such moisture regimes (Saco et al., 2006). Therefore, the understanding of processes that regulate resources in an ecological system and landscape is a fundamental step in ecosystem conservation. Landscape functioning is dependent on the conservation and use of soil, water and nutrient (collectively called "resources") within the landscape system (Tongway and Hindley, 2004; Tongway and Ludwig, 2010). Landscape Function Analysis (LFA) introduced by Tongway and Hindley (2004) is a sim- ple qualitative monitoring procedure that uses rapidly acquired field-assessed indicators to assess the biogeochemical functioning of arid and semi-arid rangelands. In rangeland inventory studies, it is possible to judge the effects of management actions by using functional analysis of ecological indicators.

Controlling and spreading flood is one of the efficient management practices in recent decades; flood control has come to be considered as one of the most effective actions for arid and semi-arid rangeland restoration and rehabilitation (Forouzeh, 2007). Being si-

\footnotetext{
Received 2011-12-28; accepted 2012-04-12

"Corresponding author: Mohsen SHARAFATMANDRAD (E-mail: sharafatmandrad@yahoo.com)
} 
mple and reasonable in comparison to other endeavors (Branson, 1956), water spreading plans are multipurpose and effective options for restoring arid and semi-arid rangelands (Forouzeh and Heshmati, 2005). Therefore, the LFA method was applied in this study to assess the effects of water spreading system on the patch function and qualitative capability of rangeland ecosystems. In rangeland inventory studies, it is possible to judge the effects of management actions by using functional analysis of ecological indicators.

Soil and vegetation parameters that are considered as representative ecological indicators of ecosystems (Pyke et al., 2002) are quantitatively measurable characteristics that indicate the dynamic condition of a habitat or natural field (Pellanet et al., 2000). Detection of changes occurring in the rangeland by the LFA method gives an understanding of natural processes and provides more capability for converting data to an applicable body of information for direct use by land managers and supervisors. Rapidly acquired fieldassessed indicators and simple tools to assess soil and vegetation parameters are two strengths of the method that duplicate its importance for use; environmental variables were shown to have a very high degree of correspondence with measured indicators (Tongway and Hindley, 2004). Plant patches or ecological patches are arrayed in terms of amplitude and ecological nature of resources; plant communities are distributed based on the tolerance of various species to different environmental resources (Heshmati, 2003).

Assessing the ecological function of rangelands requires the monitoring of both soil and vegetation factors and the understanding of them is an important step in determining the site potential. By examining rangeland functionality, current condition and trend can be investigated in relation to vegetation dynamics. Functionality of arid and semi-arid rangeland ecosystems around the world is extensively affected by ecological and hydrological processes, and feedbacks and responses at different scales (Noy-Meir, 1973; Wilcox et al., 2003; Ludwig et al., 2005; Tongway and Ludwig, 2010).

It is also important to monitor the health and functional status of rangeland patches over time in response to environmental change and management regimes imposed by land users of such ecosystems (pastoralists and/or native residents). Monitoring will allow decision-making for qualitative improvement of these ecosystems (Pyke et al., 2002). The ecohydrological viewpoint is dominative in new approaches to rangeland management; in these approaches, patches and inter-patches are considered as spaces that have different roles in retaining water and nutrients as well as controlling erosion based on their natures (Ghodsi, 2009). So assessing the functionality of patches in rangeland ecosystems provides information for day-to- day management of rangelands on the scale of a geographical region that can aid administrative procedures and utilization of land based on their potential capabilities. By assessing patches and inter-patches, and monitoring, observing, detecting, and recording their changes in natural ecosystems over time, it is possible to identify occurred ecological thresholds (Friedel, 1991) using soil and vegetation indices (Andreasen, 2001) in the ecosystems. Patch and inter-patch structures affect soil moisture in arid and semi-arid zones, and thus determine soil erosion rate. A reduction in the size, number, spacing or effectiveness of fertile patches may increase runoff and erosion in intense rainfall and cause landscape degradation (Saco et al., 2006).

One of the important points of patch assessment is the consolidation of data from smaller units (patch scale) to larger units (plant species, communities and landscapes) that can aid to make a good interpretation of rangeland condition (Tongway and Hindley, 2005). For example, by knowing the structural parameters of patches, relative distribution of patches in the rangeland can be determined, and also, by determining the functionality in each patch and considering the relative distribution of different patches in the landscape, it is possible to predict the functional characteristics of rangelands (Ghodsi, 2009). Application of ecological models that have long been used in rangeland studies can facilitate the processing of data about patches as an aid to assessment and management planning.

\section{Materials and methods}

\subsection{Study area}

The research was conducted in Gareh Bygone, 200 $\mathrm{km}$ southeast of Shiraz, Fars province $\left(28^{\circ} 35^{\prime} \mathrm{N}\right.$, $53^{\circ} 57^{\prime} \mathrm{E} ; 1,140 \mathrm{~m}$ asl). The area is part of the arid 
rangeland ecosystems of Southwest Iran. It is characterized by a mean annual precipitation of $259 \mathrm{~mm}$. The mean annual temperature is $20.6^{\circ} \mathrm{C}$ and regional climate is arid as potential evaporation exceeds precipitation by a large extent.

The study area is one of the eight watershed management stations in Gareh Bygone. For the convenience of the study, this area was divided into two parts: water spreading site and control site. The 250-hm ${ }^{2}$ water spreading site was irrigated continuously for 30 years and the $10-\mathrm{hm}^{2}$ control site was located west of the water spreading site (Fig. $1)$.

\subsection{Data collection}

Systematic-random sampling was done using the
LFA method in the water spreading and control sites respectively along five $50-\mathrm{m}$ transects with $150-\mathrm{m}$ intervals that ran parallel to the slope gradient of the study area. Each transect includes the space covered by patches as well as the distance between successive patches. Five examples of each identified patch/interpatch types were determined as replication and there were 11 soil surface indicators for each of the three indices (stability, infiltration, and nutrient cycling) according to the methods of Tongway and Hindley (2005). To assess vegetation effects on soil indicators, plant density was measured using Point Centered Quarter (PCQ) (Krebs, 1999) with a minimum of 20 points on transects. Plant canopy cover and com- position were also measured using line intercept method.

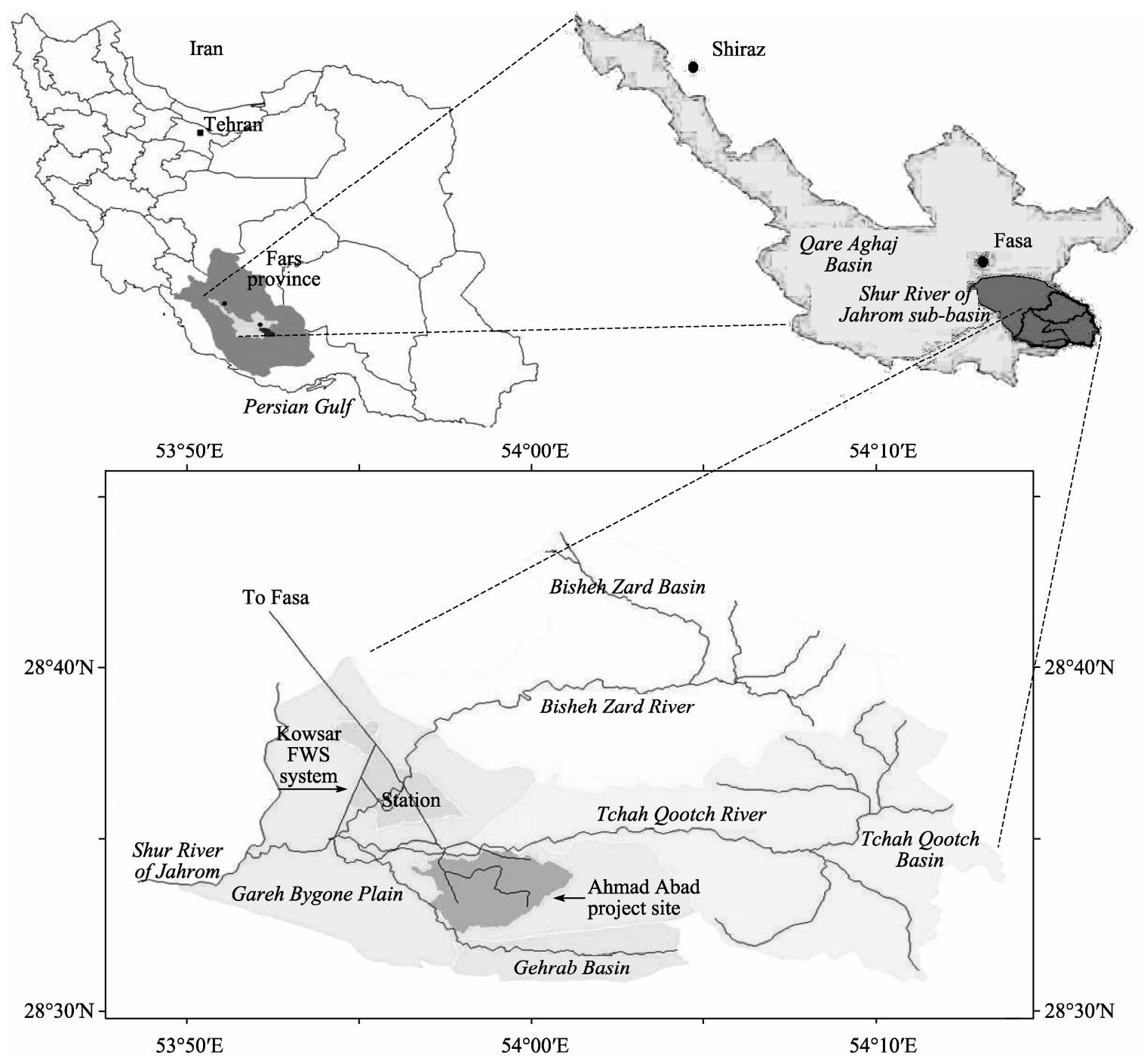

Fig. 1 The location of the Gareh Bygone water spreading system 


\subsection{Statistical analysis}

All calculations were performed using the Excel template provided by Tongway and Hindly (2004). To test the equality of the means of the three indices of stability, infiltration, and nutrient cycling in the water spreading and control sites and to assess the differences in these means, the study used the one-way analysis of variance (ANOVA) procedure at the 95\% confidence level with Duncan comparison. The SPSS version 18 statistical software package (SPSS Inc., Chicago, IL, USA) was applied.

\section{Results}

\subsection{Patches assessment}

Based on investigation, the study identified different kinds of patches and inter-patches in the study area: four kinds of patches (shrub, grass, forbs and shrubgrass) and one kind of inter-patch (bare soil) that includes space between successive patches (Fig. 2).

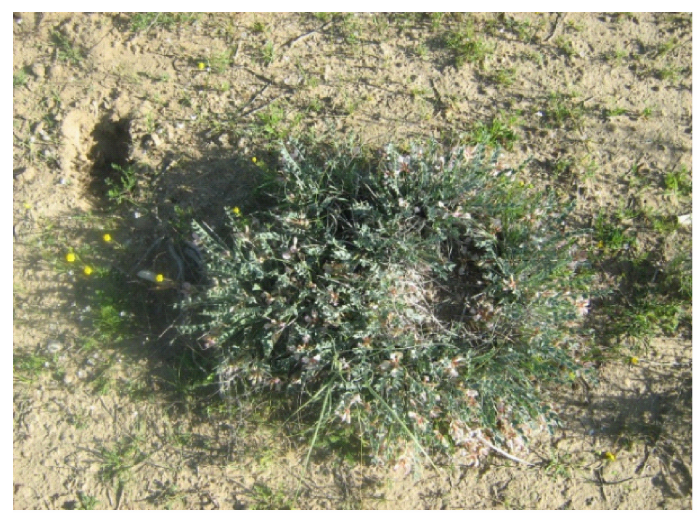

(a)

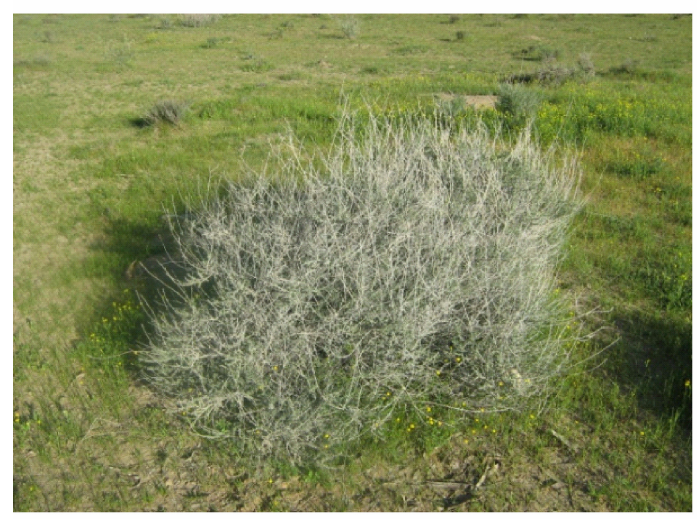

(c)
The results for the water spreading site showed that the mean length of shrubs was two times more than that of grasses and five times more than that of forbs, whereas the ratio in the control site was about four times more than those of both grasses and forbs (Table 1). The numbers of shrub, shrub-grass, grass and forb patches were 37, 10, 18 and 8 in the water spreading site and 19,13, 10 and 6 in the control site, respectively. So there was a substantial increase in the number of patches in the water spreading site in comparison to the control site, although the highest number of patches was related to shrub-dominated patches. The mean length of all patches was greater in the water spreading site than in the control site. The highest fraction of patch length in both two sites was related to the shrub and shrub-grass patches, so that the mean length of these patches in the water spreading site was three to four times more than the mean length of the same patches in the control site. Patch Area Index (total patch area/

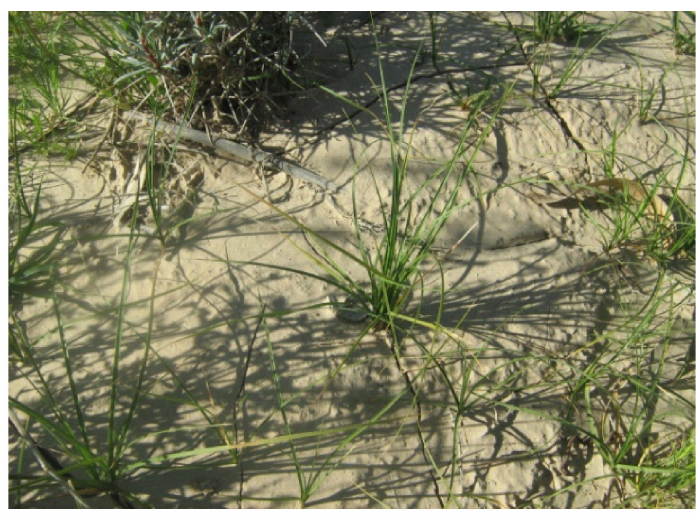

(b)

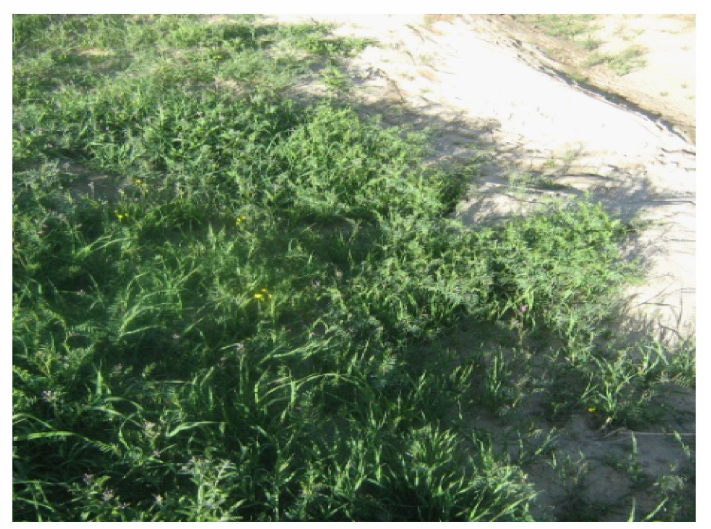

(d)

Fig. 2 Four different patches in the study area: shrub (a), grass (b), shrub-grass (c) and forb (d) 
Maximum area, if all transects were patches) in the water spreading site and the control site was 0.03 and 0.1 , respectively. Landscape Organization Index that indicates landscape potential and capability in the water spreading site was 2.15 times more than in the control site (Table 1).

\subsection{Soil surface assessment indicators}

Regardless of the number and area of patches, the results of assessment of 11 soil surface factors for the three indices of stability, infiltration and nutrient cycling in the water spreading site and the control site showed that grass patch had the highest stability index value and significant differences compared to the other patches, but there was no significant differences between the other patches in respect to stability index in both sites (Fig. 3). All patches have no significant differences in respect to infiltration index (Fig. 4). The value of nutrient cycling index was highest for the shrub-grass patch and the difference among the other patches was significant in both sites (Fig. 5).
There was no significant difference between stability and nutrient cycling indices in both sites $(P>0.05)$, but the two indices have generally been increased in the water spreading site where the infiltration index has been decreased (Figs. 3-5).

\subsection{Vegetation indices assessment}

The results showed that spreading flood water can have meaningful effects on species canopy cover, so that the canopy cover in the water spreading site was increased more than two fold than in the control site. Table 2 indicates the percentages of species composition and canopy cover for different growth forms. Shrub patches have the highest percentages of canopy cover and species composition in both the water spreading site and the control site.

Vegetation assessment showed that the densities of plants for the water spreading site and the control site were 3,256 and $1,283 \mathrm{plant} / \mathrm{hm}^{2}$, respectively; and the mean intervals between plants were 1.3 and $2.1 \mathrm{~m}$, respectively. It should be noted that flood spreading has

Table 1 The means of quantitative characteristics and patch indices in the water spreading and control sites

\begin{tabular}{|c|c|c|c|c|c|c|}
\hline Landscape & Patch & Mean length (m) & Length $(\%)$ & Mean width (m) & Patch Area Index & Landscape Organization Index \\
\hline \multirow{5}{*}{ Water spreading site } & Grass & 0.43 & 18.2 & 0.75 & \multirow[t]{6}{*}{0.03} & \multirow[t]{6}{*}{0.58} \\
\hline & Shrub & 1.96 & 27.1 & 0.62 & & \\
\hline & Shrub-grass & 1.22 & 9.2 & 0.11 & & \\
\hline & Forb & 0.34 & 10.1 & 0.06 & & \\
\hline & Litter & 0.56 & 14.0 & - & & \\
\hline \multirow{7}{*}{ Control site } & Bare soil & 0.61 & 21.4 & - & & \\
\hline & Grass & 0.15 & 4.1 & 0.38 & \multirow[t]{6}{*}{0.10} & \multirow[t]{6}{*}{0.27} \\
\hline & Shrub & 0.66 & 18.4 & 0.47 & & \\
\hline & Shrub-grass & 0.28 & 11.9 & 0.33 & & \\
\hline & Forb & 0.18 & 9.8 & 0.21 & & \\
\hline & Litter & 0.38 & 12.4 & - & & \\
\hline & Bare soil & 1.82 & 43.4 & - & & \\
\hline
\end{tabular}

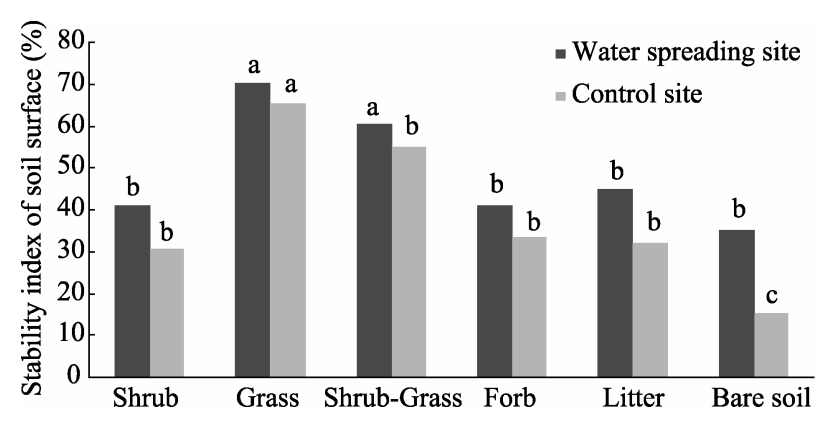

Fig. 3 Stability index of different patches without considering the number of patches; Different letters mean significance at $P<0.05$ level.

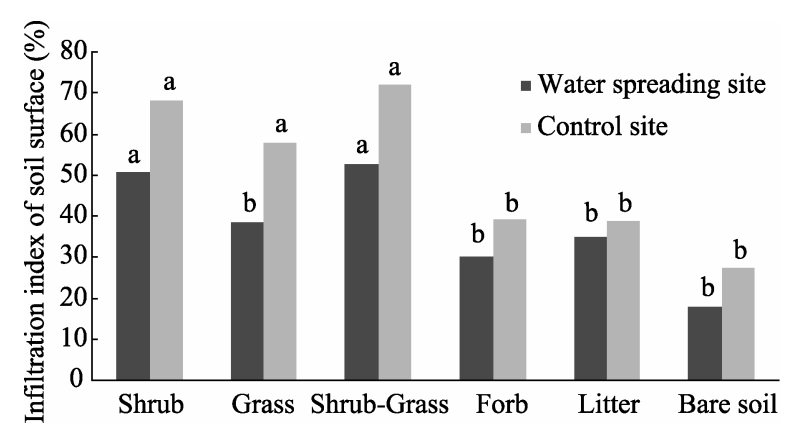

Fig. 4 Infiltration index of different patches without considering the number of patches; Different letters mean significance at $P<0.05$ level. 


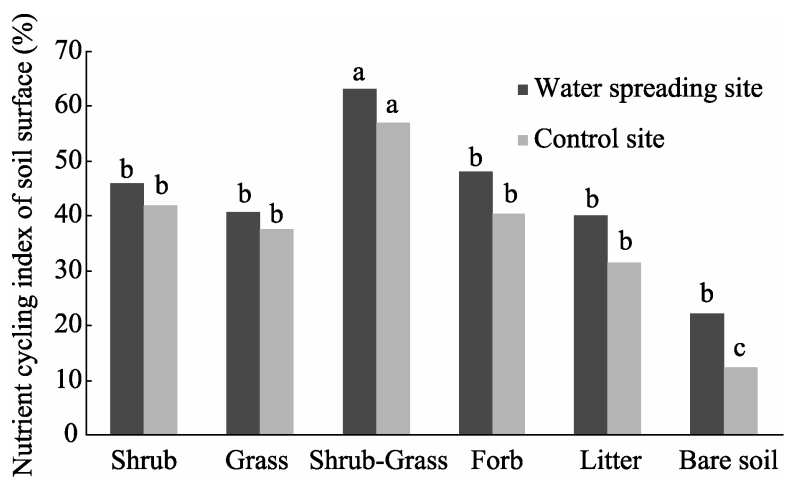

Fig. 5 Nutrient cycling index of different patches without considering the number of patches; Different letters mean significance among different patches at $P<0.05$ level.

substantial effects on shrub density so that there is a significant increase in the density of shrub patches in the water spreading site.

\section{Discussion and conclusions}

The value of Landscape Organization Index was higher in the water spreading site than in the control site, which was caused by the differences between patch structure in the two sites, i.e. there was greater number, area and uniformity of patches, especially shrub and grass patches, in the water spreading site.

The substantial increase in shrub species in the water spreading site was the consequence of seed transportation by floods from uplands and good condition for plant establishment in alluvial sediments. Forouzeh and Heshmati (2005) examined the effects of flood spreading plans on some vegetation characteristics and surface soil properties, and reported the substantial increase of shrub species in water spreading sites. There was a positive response of some shrub species to water spreading plans (Bayat Movahed and Mosavi, 2007). Researchers have also reported the reduction of wind speed, air temperature and evaporation as the result of restoration actions in arid rangelands. These changes initially caused an increase of ephemeral species, especially grasses. In general, the increase in the five patches in the water spreading site is indicative of positive effects of water spreading plans on the region's vegetation; since moisture is the most important limitation of arid land soils (Rahbar, 2006), the improvement of soil moisture condition can account for these changes. The positive effects of water spreading system on vegetation have been reported by other researchers (Suleman, 1995; Forouzeh, 2007; Movahed and Mosavi, 2007).

The value of stability index of grass patches was higher than at other patches in both sites probably because of changes in the underground parts of grasses. Underground parts of plants have an important role in the constitution of aggregation in both physical and chemical forms and lead to soil structure improvement and thereupon surface soil compactness. One of the unique characteristics of the studied grass patches is the formation of underground parts including relatively solid, thin and complicated rhizomes, scattered stolons and roots that extend to the $30-\mathrm{cm}$ depth of soil. Therefore they are able to protect the surface layer of soil. The value of the infiltration index was reduced in the water spreading site compared to the control site. The reduction of the infiltration index value can be related to the following points (Rahbar, 2006):

(1) Suspended material fills soil pores by forming a layer with low permeability on top soil, closing surface soil pores and blocking the space between soil particles in depth.

(2) Because of the absorption of dissolved cations in water and the tensile properties of ions, clay is swelled, which decreases the free space between soil particles;

Table 2 The means of canopy cover and species composition in the water spreading and control sites

\begin{tabular}{lccccc}
\hline \multirow{2}{*}{ Growth form } & \multicolumn{2}{c}{ Canopy cover (\%) } & & \multicolumn{2}{c}{ Species composition (\%) } \\
\cline { 2 - 3 } \cline { 5 - 6 } & Water spreading site & Control site & & Water spreading site & Control site \\
\hline Shrub & 24.82 & 13.37 & 43.7 & 7.7 & 5.3 \\
Perennial grass-like & 4.40 & 2.30 & 3.0 & 7.7 & 14.2 \\
Perennial grass & 1.70 & 3.60 & 24.9 & 13.5 \\
Perennial forb & 4.40 & 3.40 & 12.9 & 11.0 \\
Annual grass & 14.10 & 2.92 & & \\
Annual forb & 7.40 & &
\end{tabular}


this swelling usually happens in cases where water contains organic matter and exchangeable ions such as $\mathrm{Na}^{+}$and $\mathrm{K}^{+}$.

(3) It is possible that some of the dissolved material infiltrates into soil and sediments, and closes the soil pores because of chemical reaction, and thus reduces the infiltration rate.

(4) Growth of algae and bacteria, especially when water is rich in nutrients, causes biological clogging, and thus reduces permeability.

The value of infiltration index of shrub and shrubgrass patches was higher than that of the other patch types. It could be the result of extensive root development of shrubs, providing better condition for water infiltration into soil.

The value of nutrient cycling index in the water spreading site was higher than in the control site. It is the result of an increase in the organic matter and $\mathrm{N}$ content in the water spreading system. There is a close relationship between the amount of $\mathrm{N}$ and the increase of organic matter in arid lands since litter decomposi-

\section{References}

Andreasen J K, Neill R O V, Noss R, et al. 2001. Considerations for the development of a terrestrial index of ecological integrity. Ecological Indicators, 1: 21-35.

Bayat Movahed F, Mosavi S A. 2007. Study of water spreading impact on plant species changes in Zanjan. Iranian Journal of Range and Desert Research, 14: 222-231.

Branson F A. 1956. Range forage production changes on a water spreader in southeastern Montana. Journal of Range Management, 9: $187-191$.

Forouzeh M R, Heshmati G A. 2005. Flood water spreading in deserts as multiple practices to face with climate change crisis. International Conference of Geohazards, Natural Disasters and Methods of Confronting with Them, September 27-29, 2005, Tabriz, Iran.

Forouzeh M R. 2007. Effect of floodwater irrigation on carbon sequestration potential of dominant shrubs in Gareh Bygone of Fasa. MSc Thesis, Gorgan: Gorgan University of Agricultural Sciences and Natural Resources.

Friedel M H. 1991. Range condition assessment and the concept of threshold: a viewpoint. Journal of Range Management, 44: $422-426$.

Ghodsi M. 2009. An investigation on patch dimensions at two temporal stages and managerial levels (case study: semi-steppe rangelands of Golestan National Park and surroundings). MSc Thesis, Gorgan: Gorgan University of Agricultural Sciences and Natural Resources. tion in the top soil and organic matter increment improve $\mathrm{N}$ content of the soil (Rahbar et al., 2001). Increase of organic carbon in the water spreading site could be the result of processes such as the transport of sediments containing plant residuals from uplands into the water spreading system, the increase of vegetation cover and litter in the water spreading site, and the increase of soil saturation percentage, which regulated soil temperature and increased soil microbial activities.

The vegetation density and canopy cover of different growth forms showed a substantial increase in the water spreading site compared to the control site. It could be another reason for the increases of the two indices of stability and nutrient cycling as well as landscape organization index in the water spreading site. These results coincide with those of Tongway and Hindley (2004). In general, the results showed the improvement of ecological patches and rangeland ecosystems where water spreading systems were practiced.

Heshmati G A. 2003. Multivariate analysis of environmental factors effects on establishment and expansion of rangeland plants. Iranian Journal of Natural Resources, 56 (3): 309-320.

Krebs C J. 1999. Ecological Methodology, $2^{\text {nd }}$ ed. California: Benjamin Cummings, 620.

Ludwig J A, Tongway D T, Freudenberger D, et al. 1997. Landscape Ecology Function and Management: Principles from Australia's Rangeland. Collingwood: CSIRO Publishing, 274.

Ludwig J A, Wilcox B P, Breshears D D, et al. 2005. Vegetation patches and runoff-erosion as interacting ecohyrological processes in semiarid landscape. Journal of Ecology, 86(2): 288-297.

Newman J C. 1963. Waterspreading on marginal arable areas. Journal of Soil Conservation, 19: 49-58.

Noy-Meir I. 1973. Desert ecosystems: environment and producers. Annual Review of Ecology and Systematics, 4: 25-51.

Pellanet M, Shaver P A, Pyke D A, et al. 2000. Interpreting Indicators of Rangeland Health, Version3. Interagency Technical Reference 1734-6. Denver: United States Department of the Interior-Bureau of Land Management, National Science and Technology Center.

Phillips J R H. 1957. Level-sill bank outlets. Journal of Soil Conservation, $13(2): 13$.

Pyke D A, Herrick J E, Shaver P, et al. 2002. Rangeland health attributes and indicator for qualitative assessment. Journal of Range Management, 55: 584-597. 
Quilty J A. 1972. Soil conservation structures for marginal arable areas gap absorption and gap spreader banks. Journal of Soil Conservation, 28: 116-130.

Rahbar G R, Kowsar S A. 1997. Infiltration ability enhancement in sedimentation basins by sow bugs. Proceedings of the $8^{\text {th }}$ International Conference on Rainwater Catchment Systems, April 25-29, 1997, Tehran, I.R. Iran.

Rahbar G R, Kowsar S A, Khalili D. 2001. Soil modification by the freshly-laid sediment and colonies of sow bug (Hemilepistus shirazi schuttz) in a sandy desert. Proceedings of the First Congress of Soil Scientist of Tajikistan, November 2-3, 2001, Dushanbe, Tajikistan.

Rahbar G R. 2006. Changes in soil infiltration rate due to floodwater spreading at the Kowsar Aquifer Management Station. Proceedings of the $4^{\text {th }}$ National Workshops Sustainable Management of Marginal Dry Lands (SUMAMAD), September 12-13, 2006 and August 13-14, 2007, Kowsar Research Station, Gareh Bygon, Fasa, Iran.

Saco P M, Willgoose G R, Hancock G R. 2006. Eco-geomorphology and vegetation patterns in arid and semi-arid regions. Hydrology and Earth System Sciences Discussions, 3: 2559-2593.

Suleman S, Wood M K, Shah B H, et al. 1995. Rainwater harvesting for increasing livestock forage on arid lands of Pakistan. Journal of Range Management, 48(6): 523-527.

Tongway D J, Hindley N L. 2004. Landscape Function Analysis: a system for monitoring rangeland function. African Journal of Range and Forage Science, 21: 109-113.

Tongway D J, Hindley N L. 2005. Landscape Function Analysis Manual: Procedures for Monitoring and Assessing Landscapes with Special Reference to Mine sites and Rangelands, Version 3.1. Canberra: CSIRO Sustainable Ecosystems, 55: 584-597.

Tongway D J, Ludwig J A. 2010. Restoring Disturbed Landscapes: Putting Principles into Practice. Washington DC: Island Press.

Wilcox B P, Breshears D D, Allen C D. 2003. Ecohydrology of a resource-concerning semiarid woodland: effects of scale and disturbance. Ecological Monographs, 73(2): 223-239. 